\title{
COMPONENTS OF AUTOMATED INTELLECTUAL SYSTEMS SUPPORTING DECISIONS AT THE STAGE OF OPERATION AND EQUIPMENT DIAGNOSTICS OF NUCLEAR POWER UNITS
}

\author{
O.V. Yefimov ${ }^{1}$, M.M. Pylypenko ${ }^{2}$, T.V. Potanina ${ }^{1}$, T.O. Yesypenko ${ }^{1}$, \\ V.L. Kavertsev ${ }^{1}$, T.A. Harkusha ${ }^{1}$ \\ ${ }^{1}$ National Technical University "Kharkiv Polytechnic Institute", Kharkiv, Ukraine \\ E-mail: AVEfimov@kpi.kharkov.ua; \\ ${ }^{2}$ National Science Center “Kharkov Institute of Physics and Technology”, Kharkiv, Ukraine
}

The results of studies of parameters, characteristics and performance of NPP units by mathematical modeling methods using computer-integrated technologies for their implementation, which allow to simulate many functional states of systems and equipment of NPP units during the simulation experiment are presented. The general structure of interaction of blocks of software complex for analysis of efficiency of work and parametric diagnostics of NPP units with WWER is developed. The structure of the block of programs of parametric diagnostics of equipment of NPP units is presented. The essence of methods and approaches of parametric diagnostics of power unit equipment is considered.

\section{INTRODUCTION}

It is known that nuclear power plant units, which are complex technical systems, are characterized by a large number of parameters, multifunctional links between them, a variety of equipment for various technological purposes and physic-chemical processes occurring in it, as well as operation under the influence of external random processes, etc.

To study the parameters, characteristics and performance of NPP units as complex technical systems methods of mathematical modeling using computerintegrated technologies for their implementation are now widely used. They make it possible to simulate the set of functional states of both systems and equipment of power units in a simulation experiment [1-19].

Technological processes occurring in the equipment of NPP units at various modes of their operation, including dynamic (transient), are generally described by complex systems of nonlinear differential equations in partial derivatives. For the description of technological processes at stationary (quasi-stationary) modes of operation of power units non-linear equations are used, which have their own peculiarities. Numerical methods are used to solve them in the process of simulation, and sometimes their linearization, which makes it possible to obtain an approximate solution with sufficient accuracy for engineering practice [1-3].

\section{LITERATURE DATA ANALYSIS AND PROBLEM STATEMENT}

Functional state modeling and diagnostics of power equipment on the example of turbines are presented in [1]. Optimization of models, processes, structures and modes of operation of NPP power equipment and mathematical modeling of technological processes occurring in reactors and steam generators of NPP units are described in $[2,3]$. In order to solve the problems of analysis, control and diagnostics in the articles [4, 5], the authors proposed a simulation model of NPP units with WWER-1000. And the automated decision support system for nuclear power plant operators is described in
$[6,7]$. Studies [8-11] are devoted to the development of new generation nuclear reactor structures and their elements using simulation methods. Methods of constructing diagnostic models of power equipment are described in detail in [12-14]. The application of mathematical modeling methods to calculate various performance indicators for power plants is presented in studies [15-20]. Articles [21-23] formulate the conceptual foundations of the theory of simulation modeling and construction of integrated automated systemof operation of power plants. The issue of optimal load distribution between power units of nuclear power plants based on modern methods of mathematical modeling is considered in [24, 25].

The main component of the approaches presented in these works are mathematical (simulation models), which adequately describe the technological processes, both in individual elements and in the unit as a whole, and their computer implementation in the form of an automated set of programs that can serve as a basis for creating automated intellectual decision supporting system (ADSS) by operating and repair personnel of NPP units.

ADSS allows to solve the following tasks:

- calculation of the parameters of technological processes in the elements, nodes and systems of the power unit;

- parametric diagnostics of the technical state of power unit equipment;

- calculation of indicators of reliability and safety indicators of systems and equipment of the power unit;

- calculation of the projected electricity and heat generated by the power unit in a given period of operation;

- calculation of the technical and economic indicators of the unit's efficiency;

- calculation of the performance indicators of repair work (repair cycles) at the power unit.

The effectiveness of using such ADSS in the process of operation of NPP units as parts of their automated system of operation, the accuracy and number of decision-making options offered by the system 
significantly depend on the level of the unit simulation model detailing and the accuracy of the mathematical methods used in the computer programs of the abovementioned calculations to describe the technological processes in the equipment of the units.

The purpose of this article is to describe the results of the research aimed at developing computer-integrated components of one of the ADSS variants for operational and maintenance personnel of NPP units according to the criterion of technical and economic efficiency, taking into account the diagnostics of the technical equipment state based on the simulation model describing by means of up-to-date mathematical methods the technological processes in the main and auxiliary equipment of power units using up-to-date mathematical methods at the level of detailing, corresponding to their principle and deployed thermal schemes. This simulation model, methods and approaches to its creation based on the graph theory are described in sufficient detail in [1,3-6] and several others.

\section{COMPUTER-INTEGRATED COMPONENTS AND THE MATHEMATICAL METHODS OF THE IR IMPLEMENTATION}

Based on the simulation model of the NPP power unit with WWER-1000, computer-integrated components of ADSS were developed as a set of computer programs for analyzing technical and economic efficiency of operation and parameter diagnosing the technical state of two-loop cycle NPP unit equipment.

These components are used for a new, more advanced version of the automated complex of programs for analyzing the operation of two-loop cycle NPP units [6], expanded by developing programs for computing diagnostic parameters of the main and auxiliary equipment of power units.

The structure of individual components (blocks) of the automated computer program complex for analyzing technical and economic efficiency of operation and parameter diagnosing NPP power units with WWER is shown in Fig. 1.

This set of programs, which is controlled by the MAIN file (see Fig. 1), can be divided into two parts: conservative and operational, which is quite typical for automated decision-making support systems for operational personnel of power facilities as complex technical systems [6].

The conservative part of the program complex, which provides the adequate description of the technological processes in the systems and equipment of the NPP power unit at different operation modes, includes:

- a database operation block, which is used to store the information accumulating during the operation of the power unit (see Fig. 1);

- a block for processing information about the values of the parameters and characteristics of technological processes in the power equipment received from the instrumentation of the power unit (see Fig. 1);
- a block for identifying the simulation model with the actual technical state of the power unit equipment (see Fig. 1);

- a block of the modification of the structure and parameters of thermal power unit scheme (TS) that provides for connecting, disconnecting, switching, replacing, eliminating and including equipment into the $\mathrm{TS}$, as well as entering and correcting the initial data necessary to compute the parameters of the technological processes in the power unit equipment (see Fig. 1).

The operational part of the program complex, which provides the computation of parameters in the power unit systems and equipment, contains the following program blocks:

- a block of programs for computing parameters, characteristics and indicators in the reactor plant equipment by means of the corresponding algorithms given in [2, 3], including programs for computing thermal and hydraulic parameters and characteristics of the heating agent in the primary loop equipment, in particular, in main circulation pumps, as well as working substance in steam generators;

- blocks of programs for computing the parameters, characteristics and indicators of the turbine installation by means of the corresponding algorithms given in [2, 3], including: a block of programs for computing the parameters, characteristics and indicators in the flow sections of the main turbine and the turbo drive of the feed pump; blocks of programs for computing the parameters, characteristics and indicators in the systems of condensation and regenerative heating of the main condensate and feed water; a block of programs for computing the parameters, characteristics and indicators in the system for heating the network water (heating system);

- a block of programs for the parameter diagnostics of the main and auxiliary equipment in the power unit, created on the basis of the approaches, methods and models described in detail in [1-3].

Let's consider the essence of methods and approaches for parameter diagnostics of power unit equipment.

Technical state of the unit equipment during its operation is determined by the values of the set of diagnostic features (functions) $D(W)$, which are measures of the quality of its functioning at the moment $\tau_{j}, \tau_{j} \in\left[\tau_{0}, \tau\right]$. Automated diagnostics of the technical condition of the NPP unit equipment can be performed with the help of mathematical models of technological processes that occur in the equipment and which are integrated into the simulation model of the unit $[1,2$, 26]. The simulation model of the power unit, which is organized in the form of logical and numerical operators of the calculation of technological process parameters, allows to determine technical and economic performance of the unit and mutual influence of the equipment parameters. The analysis of these data in specific operating conditions allows us to determine the most significant constant and changing parameters and to form the characteristics of the predicted background. 


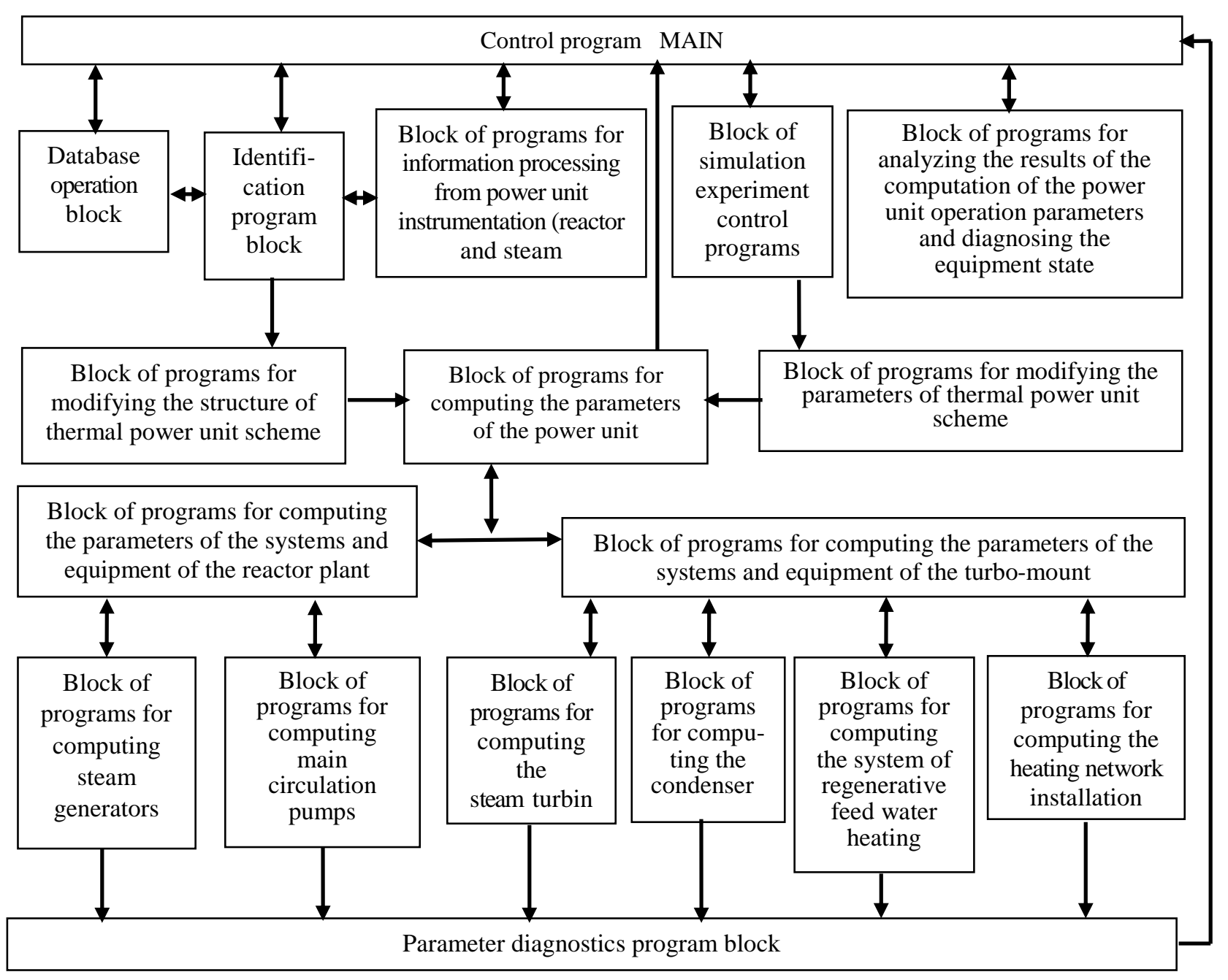

Fig. 1. The structure of the interaction of components (blocks) of the automated system performance analysis

Among the criteria which are crucial in making a decision on the repair because of the technical condition of systems and equipment, an important indicator is the impact of changes in equipment parameters and its failure on the efficiency of the production of electrical and thermal energy. Determining the rate of decline (relative to the average level) of the performance indicators of systems and equipment on the basis of the data of the integrated operation characteristics of power units $[1,25]$, it is possible to find out the optimal service life, predict the duration of the inter-repair periods and the term of their economically justified removal for the repair. In the case of forecasting the technical and economic level of the unit equipment, the analysis of its behavior in specific operating conditions allows to select the most essential (informative) steels and variables, to form the characteristics of the forecast background and, in such a way, to obtain a sufficient amount of diagnostic features. With the help of operational characteristics it is possible to arrange parameters according to their influence on the status of systems and equipment of power units $[1,5]$.

The process of the automated diagnostics of the technical state of the equipment of NPP units can be represented by the following procedure:
- planning and organizing a series of inspections $\Pi=\left\{\pi_{1}, \ldots, \pi_{l}\right\}$, which are experiments $A_{k}, k=\overline{1, l}$ with the power unit simulation model for all the equipment to be diagnosed;

- determining in the course of operation the input impact value on the basis of indicators of controlmeasuring devices of the system of thermal automatics and measurements of the power unit $Y_{k}, k=\overline{1, l}-$ the initial data coming into the simulation model of the power unit, and the model response to that influence, as the value of the diagnostic function $D\left(W\left(Y_{k}\right)\right)$ (test result). To do this, the task of optimizing the selection of inspections that determine the technical state of the unit equipment is pre-solved. The total number of inspections $\pi_{k}, k=\overline{1, l}$ should be minimal and each inspection should contain the maximum amount of information $I_{\pi_{k}} \rightarrow \max$;

- comparing the values of diagnostic functions $D\left(W\left(Y_{k}\right)\right)$, obtained as a result of the simulation experiment on the power unit simulation model with their measured and normative values in order to make a diagnostic conclusion about the causes and factors of changes in the technical equipment condition and determine the time remaining before its failure. 
In the general case, in the diagnostics of the technical state of the power unit equipment by means of a simulation model, the multi-parameter function $W=W(\vec{X}(\tau))$ is a diagnostic function. It characterizes the effect of changes over time $t$ on the equipment parameter vector $X=\left\{X_{1}, \ldots, X_{m}\right\}$, which reflect the deterioration in performance during the inter-repair period, on the efficiency of the unit operation. The power unit simulation model allows us to obtain dependencies that predict the effect of changes in each of the parameters $X_{r}$ on $W$ over time $t$ : $W_{r}=W_{r}\left(X_{r}(\tau)\right), r=\overline{1, m}$.

Since the predicted processes of changes in the power unit equipment operation characteristics during the repair period are random functions of time $\tau_{j}, \tau_{j} \in\left[\tau_{0}, \tau\right]$, the apparatus of the theory of random processes can be applied to their image. In this case, for a fixed point of time $\tau_{j}, \tau_{j} \in\left[\tau_{0}, \tau\right]$, the random process $\xi^{r}(\tau)$ is the random variable, characterized by onedimensional density of distribution $f\left(x_{r}, \tau_{j}\right)$.

The result of the probabilistic forecasting of changes in the power unit equipment parameters is the calculated probability for its working state $P_{r \text { work }}\left(\xi^{r}\left(\tau_{j}\right)<g_{r}\right)=\int_{x_{r \min }}^{x_{r \max }} f\left(x_{r}, \tau_{j}\right) d x_{r}, \quad r=\overline{1, m}$, where $f\left(x_{r}, \tau_{j}\right)$ is the known probability density of a random process section at the moment $\tau_{j} ; g_{r}$ is a valid value of $x_{r}$.

The simulation model of the power unit allows to determine the cumulative effect of changes over time $k$ of the power unit equipment parameters on its performance indicators: $W_{\Sigma}=\sum_{i=1}^{k} W_{i}\left(X_{i}\left(\tau_{j}\right)\right), k \leq m$. The probability of such an impact is $P_{\Sigma}=\prod_{i=1}^{k} P_{i \text { work }}$.

The measurement of technological parameters by means of control and measuring devices in the course of the power unit operation is carried out, as a rule, in the conditions of various random obstacles and errors. Taking this into account, the measurement results of the multivariable diagnostic function $W$ at a fixed point of time $\tau_{j}$ on the operating equipment can be regarded as interval estimation, that is, the interval between statistics containing with certain probability a true value of $W$.

Thus, the measured function $W$ can be considered a random variable from the sampling of $n$ measurements with unknown mean $\mu$. In probabilistic theory of mathematical statistics, a sampling is a set of independent randomly distributed in a similar way variables. However, careful analysis of most real-world practical problems shows that what is known is not sampling $W_{i}^{l}$ but quantities $W_{i}^{l^{*}}=W_{i}^{l}+\varepsilon^{l}$, where $\varepsilon^{l}-$ certain errors in measurements, observations, analysis, experiments, and studies (e. g. instrumental errors).

One reason is to record the results of observations with a finite number of significant figures. And, thus, it is important to build the statistics on which the statistical conclusions are based and which is used to evaluate the parameters and characteristics of the distribution and test of hypotheses $W_{i}^{*}$ according to the principle, that the value of statistics from variable $W_{i}^{*}$, but not $W_{i}$ is known. If the errors meet the condition $\forall l:\left|\varepsilon^{l}\right| \leq \Delta$, then the initial data are presented in the form of intervals $\left.\mid W_{i}^{l}-\Delta ; W_{i}^{l}+\Delta\right\rfloor$, and the restriction on the errors can be set in different ways - in addition to absolute, relative, as well as other indicators of the difference between $W_{i}^{*}$ and $W_{i}$ can be used.

Based on the rules of classical statistics, we can state the following. The minimum and maximum values of function $W$ in the sampling can be taken as the lower and upper bounds of the confidence interval $W_{\min } \leq W \leq W_{\max }$ and the value $(1-\alpha)$ can be considered as the confidence probability ( $\alpha-$ the accepted level of significance). If it is known that the distribution $w$ is normal, then the value $\frac{(\bar{W}-\mu) \sqrt{n}}{S}$ is to go through Student's $t$ - distribution with $(n-1)$ degrees of freedom. Here $\bar{W}$ is the sampling mean of the results of measurements of multivariable function $W$, that is $\bar{W}=\frac{1}{n} \sum_{v=1}^{n} W_{v}$, and $S$ is the sampling variance $S^{2}=\frac{1}{n-1} \sum_{v=1}^{n}\left(W_{v}-\bar{W}\right)^{2}$. It should be added that, with a small number of observations, normality cannot be reliably established, and as the sampling size increases, the Student's quantile of the distribution becomes closer to the quantile of the normal distribution.

Then the percentage confidence interval for the diagnostic function $W$ takes the form $\mu=\bar{W} \mp t_{n-1}^{1-\alpha / 2} S / \sqrt{n}$, where $t_{n-1}^{1-\alpha / 2}$ - the quantile of t-Student's distribution with $(n-1)$ number of degrees of level freedom $\left(1-\frac{\alpha}{2}\right)$.

This statement is used to construct, based on measurement results, a series of confidence intervals of the diagnostic function $w$ that differ from each other by the probability of determining the values of this function in each of the intervals

$$
P_{W}\left(-t_{n-1}^{1-\alpha / 2}<\frac{(\bar{W}-\mu) \sqrt{n}}{S}<t_{n-1}^{1-\alpha / 2}\right)=1-\alpha .
$$

The application of interval statistics methods determines another confidence interval for mathematical expectation $\mu$ for a given confidence probability 
$(1-\alpha): \quad\left[\mu-\Delta-u(\alpha-1) \frac{S}{\sqrt{n}} ; \mu+\Delta+u(\alpha-1) \frac{S}{\sqrt{n}}\right]$, where $u(\alpha-1)$ - is the quantile of $\frac{(\alpha+1)}{2}$ order of the standard normal distribution with zero mathematical expectation and single variance. That is, as the sampling size increases, the length of the confidence interval cannot be less than $2 C \cdot \Delta$, where $C$ is a constant note estimation (the note is the value of the maximum deviation caused by the observations errors $\varepsilon$ : $N\left(\varphi\left(W_{i}\right)\right)=\sup _{\varepsilon}\left|\varphi\left(W_{i}\right)-\varphi\left(W_{i}^{*}\right)\right|_{\varphi-\text { statistics }) .}$

However, the important advantage of estimating $\mu$ in this way is not only the spread of the interval and taking into account the errors of observations, but also the fact that the distributions of the results of observations in many practical problems are often different from the normal ones.

In the process of diagnostics, the comparison of the mean of the diagnostic function $\bar{W}_{\text {instr }}$ and the value of the same function $W_{\Sigma}$, calculated by the simulation model of the power unit, which is the sum of the effects of individual possible causes (positive test result $\pi_{k}$ ) at the time $\tau_{j}$, corresponding to the measurements is performed. This is done by using the statistical theory of testing alternative hypotheses

$$
\left\{\begin{array}{l}
H_{0}: W_{\Sigma}=\bar{W}_{\text {instr }} \\
H_{1}: W_{\Sigma} \neq \bar{W}_{\text {instr }}
\end{array}\right.
$$

The hypothesis $H_{0}$ is rejected if the absolute value of statistics $\left|t_{0}\right|=\left|\frac{\left(W_{\Sigma}-\bar{W}_{i n s t r}\right)}{s / \sqrt{n}}\right|>t_{n-1}^{1-\alpha / 2}$.

In this case, in the process of diagnostics it can be concluded that $W_{\Sigma} \neq \bar{W}_{\text {instr }}$, and the value $\mid W_{\Sigma}-$ $\bar{W}_{\text {instr }} \mid=\Delta W$ is used to make decisions about the reasons that have affected the technical condition of the equipment. The lower $\Delta W$, the higher the probability of the fact that these causes have changed the condition of the equipment. Those reasons for which $W_{\Sigma}$ is within the confidence interval $=\mp t_{n-1}^{1-\alpha} / 2 \cdot S / \sqrt{n}$, where the probability of a possible error $\alpha$ is minimal, are most probable. The probability of making a decision as a result of diagnostics is equal to $P=(1-\alpha) \prod_{i=1}^{k} P_{i \text { work }}$. If the hypothesis $H_{0}$, is fulfilled, that is, if the probability of $W_{\Sigma}=\bar{W}_{i n s t r}$, the decision making probability will be maximal (because the probability of error is zero): $P=\prod_{i=1}^{k} P_{i \text { work }}$.

The approach of interval data statistics to determining the "true" threshold value $C$ in hypothesis testing, which meets the criterion actually applied, is within the interval of two notes. It is advisable to replace the threshold value with the value which is one note bigger. This ensures that the probability of rejecting the null hypothesis, if it is true, is not more than $\alpha$.

To determine the dependencies that describe the change in the technical condition and reliability of the equipment, as well as the time remaining before its failure, the following approach is proposed to plan the timing and duration of repairs and calculate the unit availability factor.

Within the predicted time interval of the unit operation, the parameters of its equipment are to be modernized as a result of changing the technical condition of the equipment. Due to the stability of physicochemical processes that cause these changes, the parameters are continuous and monotonic functions of time $t$, which can be considered as semi-Markov dependencies with known approximations of their realizations. These approximations are represented by different functions. In the practice of operation of the equipment of NPP units, linear and exponential functions are most frequently found. They can be presented as $x_{r}(\tau)=\alpha_{r}+\beta_{r} \cdot \tau$ and $x_{r}(\tau)=c_{r} \cdot e^{\gamma_{r} \tau}$ respectively, where $r=\overline{1, m}$.

With the beginning of the equipment operation at the moment of time $\tau_{0}=0$, with the help of the regular or special system of measuring instruments of the unit and its simulation model, technical condition of the equipment is diagnosed within the whole operation time interval $\delta \tau=\tau-\tau_{0}$ and, thus, the realization of functions $x_{r}(\tau), r=\overline{1, m}$ is observed consistently until the end of the predicted interval of operation $\tau$. From the discrete realization values obtained in the process of observations in points $\tau_{j}, \tau_{j} \in\left[\tau_{0}, \tau\right]$ the best extrapolation curves $x_{r}(\tau), r=\overline{1, m}$ are selected, that is, the coefficients $\alpha_{r}, \beta_{r}$ or $c_{r}, \gamma_{r}$ of approximation dependencies are calculated, with each new value of the observed realizations specify the forecast curves $x_{r}(\tau), r=\overline{1, m}$. The point of intersection of function $x_{r}(\tau), r=\overline{1, m}$, that describes the change in the technical condition of the diagnosed equipment with the set limit $g_{r}, r=\overline{1, m}$, which determines the limit value of this function, based on the technical and economic indicators of the unit or its reliability, is interpreted as the equipment to failure. This allows you to determine the time $\Delta \tau=\tau^{*}-\tau_{j}$, remaining to the necessary repair of the equipment (to its failure) $\tau^{*}$ from the moment of the technical condition diagnostics $\tau_{j}$.

The dependencies $x_{r}(\tau), r=\overline{1, m}$, that are built for the entire set of equipment in operation constitute the parameter evolution database of the state and reliability of the equipment for specific types of NPP units and their operating conditions. Such database can be applied at different stages of the life cycle of power units, including for planning the duration of power plant repair work and determining the installed capacity utilization rate or the availability factor. 
The structure of the parameter diagnostics program block is presented in Fig. 2. The factors causing the deviation of diagnostic parameters (functions) from standard values for various dimensions of the power equipment of NPP power units with WWER are summarized, systematized and entered into the database of the program complex.

Computer-integrated components in the form of a program complex allow to solve the following types of problems arising during the operation of NPP power units with WWER:

- problems of analyzing the influence of the equipment parameters, the structure of thermal schemes and external operating conditions on the performance of power units;
- problems of structural and parameter optimization of the performance indicators of power units;

- problems of optimal distribution of electrical and heating loads in time $t$ between $n$ power plant units depending on the technical state of their equipment under various external operating conditions in order to achieve optimal performance indicators of the entire NPP;

- the problems of evaluating the performance of power units during the forecast period of their operation $t$ based on the analysis of reliability indicators $R(t)$ (for example, probability of failure-free operation) of their thermal schemes and equipment obtained by means of technical state parameter diagnostics.

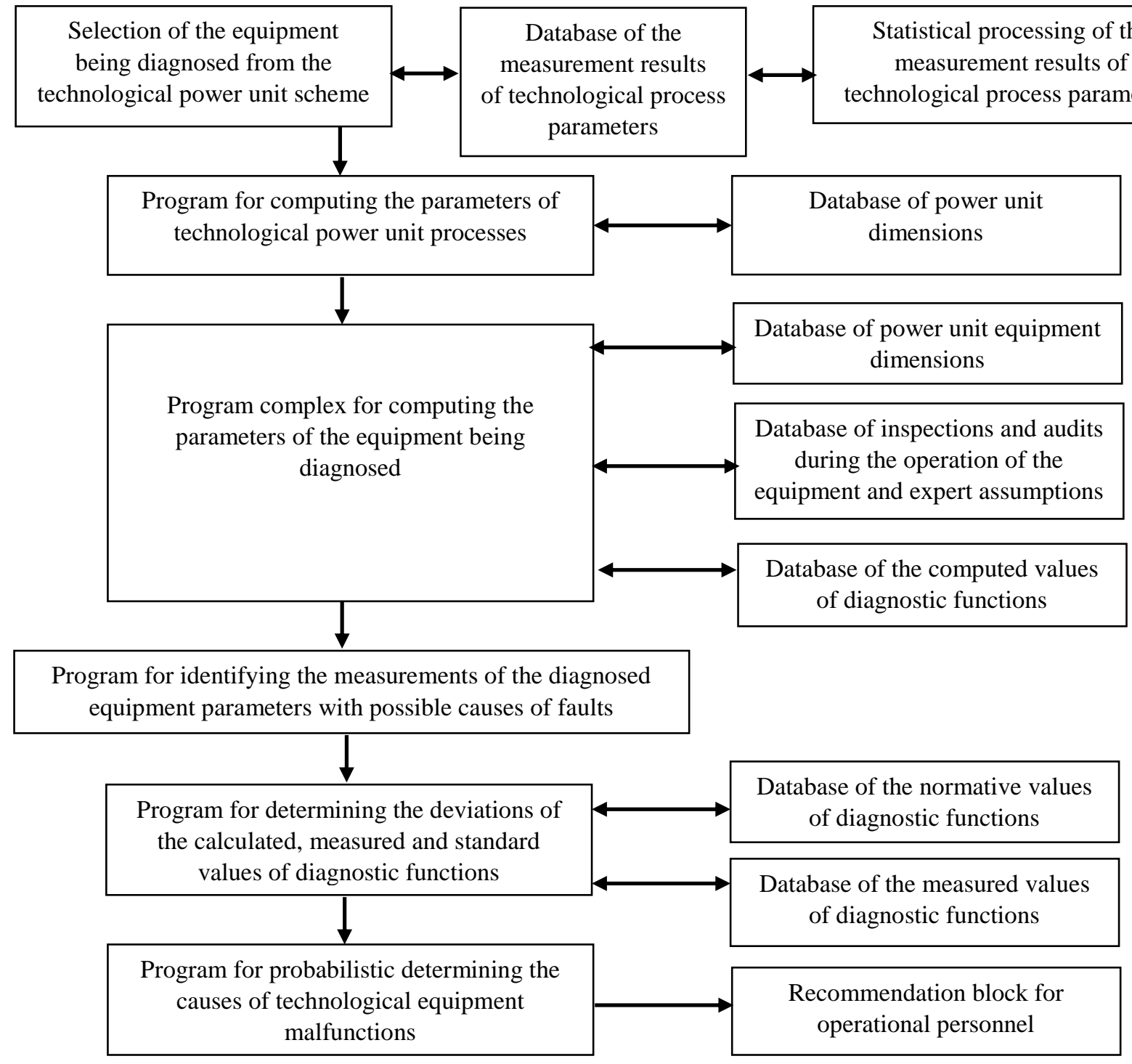

Fig. 2. Block of programs for parameter diagnostics of NPP power unit equipment with WWER

\section{DISCUSSION OF THE RESEARCH RESULTS}

The analysis of the results of computing a number of specific problems of the above-mentioned types using the described complex of programs showed that their values in terms of the initial data error, caused by errors in measuring technological process parameters by means of standard instrumentation, as well as errors in formula which were used in the computation algorithms, do not exceed the limits acceptable for assessing technical and economic efficiency, reliability and safety of NPP power units. 


\section{CONCLUSIONS}

Developed on the basis of the described computerintegrated components, the automated decision-making support system for the operational and maintenance personnel of NPP power units can be used to solve a wide range of problems arising in the practice of short-, medium- and long-term control of the operation modes of power unit systems andoptimizing operation modes and parameters, diagnosing and forecasting technical state of power equipment, predicting the amount of electrical and thermal energy generated by a power unit, as well as optimizing NPP repair cycles.

\section{REFERENCES}

1. А.А. Палагин, А.В. Ефимов, Е.Д. Меньшикова. Моделирование функционального состояния $u$ диагностика турбоустановок. Киев: «Наукова думка», 1991, 192 с.

2. А.В. Ефимов, Л.В. Гончаренко, Т.В. Потанина, В.Л. Каверцев, Е.Д. Меньшикова, А.Л. Гончаренко, Т.А. Гаркуша, Т.А. Есипенко, Л.С. Молль, А.М. АльТувайни. Совершенствование $u$ оптимизация моделей, процессов, конструкций и режимов работы энергетического оборудования АЭС, ТЭС $и$ отопительных котельных. Харьков: «Підручник» НТУ «ХПІ», 2013, 376 c.

3. О.В. Сфімов, М.М. Пилипенко, Т.В. Потаніна, В.Л. Каверцев, Т.А. Гаркуша. Реактори $i$ парогенератори енергоблоків АЕС: схеми, процеси, матеріали, конструкиії, моделі. Харків: ТОВ «В справі», 2017, 420 с.

4. T.V. Potanina, A.V. Yefimov. Development of WWER-1000 nuclear power plant generating unit imitation model for solution of analysis, control and diagnostics tasks // Transactions of Modeling-2006 Conference. Pukhov Power Engineering Modeling Problems Institute, National Academy of Science of Ukraine. 2006, p. 217-220.

5. T.V. Potanina, A.V. Yefimov. Symulacyjne modelowanie funkcjonowania energobloku elektrowniatomowej z reaktorem WWER-1000 // Nauka $i$ studia. 2009, N 2(14), p. 59-69 (in Russian).

6. A. Yefimov, D. Kukhtin, T. Potanina, T. Harkusha, B. Kavertsev. Operationeal personnel decision-making support automatic system at nuclear power plant generating units by criterion of technical ecjnjmic efficiency with due consideration of reliability factors // Nuclear and Radiation Safety. 2018, N 2(78), p. 3-11.

7. А.Н. Анохин. Адаптивный человеко-машинный интерфейс для операторов атомных станиий // Сб. научн. работ СНУЯЕ и П. 2013, №2(46), с. 16-24.

8. G.H. Marcus, A.E. Levin. New designs for nuclear renaissance // Physics Today. 2002,v. 55, N 4, p. 54-60.

9. J.M. Hoffman. Nuclear's new are // Machine Design. 2001, v. 73, N 18, p. 93-98.

10. A technical roadmap for generation IV nuclear systems: Technical roadmap report. Washington: NERAC, 2002, $112 \mathrm{p}$.

11. Generation IV roadmap: Crosscutting fuels and materials $R \& D$ scope report. Issued by the Nuclear energy research advisory committee and the generation IV international forum. 2002, 76 p.

12. A. Gardzilewicz, A. Jefimow. The heat and flow diagnostic procedure leading to a steam turbine repair Plan // Proc. $10^{\text {th }}$ Conf. on Steam and Gas Turbines for Power and Cogeneration Plants. Karlovy Vary (Czech. Rep.). 1994, p. 87-93.

13. A. Gardzilewicz, A. Jefimow. Thermal Diagnostics of Thermal Cycle Components on an Example of a Regenerative Heat Exchanger Rep. // IFFM-PAS 256/94, Gdansk, 1994, p. 34-40.

14. J. Gluch, A. Gardzilewicz. The analysis of performance of the turbine condenser with the prognosis of repair // Proc. of the International Joint Power Generation Conf. Baltimore, Maryland (USA), 1998, v. 2, p. 179-190.

15. G. Dudek. Ekonomiczny rozdzial obciażenia stosowanie algorytmów ewolucyjnych: Rozprawa doktorska. Tom 1. Czestochowa, 2002, 199 p.

16. G. da Costa, C. Costa, A. de Souza. Comparative Studies of Optimization Methods for the Optimal Power Flow Problem // Electric Power Systems Research. 2000, v. 56, p. 249-254.

17. H. Wei. An Interior Point Nonlinear Programming for Optimal Power Flow Problems with a Novel Data Structure // IEEE Trans. on Power Systems. 1998, v. 13, N 3, p. 870-877.

18. V. Miranda, D. Srinivasan, L. Proenca. Evolutionary Computationin Power Systems // Electrical Power and Energy Systems. 1998, v. 20, N 2, p. 89-98.

19. G. Dudek. Algorytm genetyczny jako metoda optymalizacji doboru składu jednostek wytwórczych w systemie elektroenergetycznym // Materiaty konferencyjne: "Algorytmy Ewolucyjne i Optymalizacja Globalna”. Lądek Zdrój, Warszawa. 2000, p. 51-58.

20. L. Shi, G. Xu. Self-Adaptive Evolutionary Programming and Its Applications to Multi-Objective Optimal Operation of Power Systems // Electric Power Systems Research. 2001, v. 57, p. 181-187.

21. В. Девид Кельтон, Аверилл М. Лоу. Имитациионое моделирование. Классика CS. С-Пб.: «Питер»; К.: Изд. Группа ВНР, 2004, 847 с.

22. B.B. Zeigler, H. Praehofer, T.G. Kim. Theory of Modeling and Simulation. Academic Press, 2000, 510 p.

23. М.А. Дуэль. Концептуальные основы построения интегрированной АСУ электростанций // Енергетика та електрифікація. 2007, №8, с. 16-24.

24.С.Н. Пелых, В.Е. Баскаков, Т.В. Цисельская. Комплексный критерий эффективности алгоритма маневрирования мощностью РУ с ВВЭР-1000 в переменном режиме // Tруды Одес. политехн. ун-та. 2009, в. 2(32), с. 53-58.

25. T. Potanina, A. Efimov. Problem of optimalload distribution between power units on the power stations // MOTROL. Lublin, 2009, v. 11A, p. 25-30.

26. D.I. Kukhtin, A.V. Yefimov, T.V. Potanina, T.A. Garkusha. Mathematical models of power plant generating unit systems and equipments for automatic mode and operation control // Vestnik NTU KPI. 2015, N 45(1154), p. 96-104. 


\title{
КОМПОНЕНТЫ АВТОМАТИЗИРОВАННЫХ ИНТЕЛЛЕКТУАЛЬНЫХ СИСТЕМ ПОДДЕРЖКИ ПРИНЯТИЯ РЕШЕНИЙ НА ЭТАПЕ ЭКСПЛУАТАЦИИ И ДИАГНОСТИКИ ОБОРУДОВАНИЯ ЯДЕРНЫХ ЭНЕРГОБЛОКОВ АЭС
}

\author{
А.В. Ефимов, Н.Н. Пилипенко, Т.В. Потанина, Т.А. Есипенко, В.Л. Каверцев, Т.А. Гаркуиа
}

Представлены результаты исследований параметров, характеристик и показателей работы энергоблоков АЭС методами математического моделирования с использованием компьютерно-интегрированных технологий их реализации, которые позволяют имитировать в процессе имитационного эксперимента множество функциональных состояний систем и оборудования энергоблоков АЭС. Разработана общая структура взаимодействия блоков программного комплекса для анализа эффективности работы и параметрической диагностики энергоблоков АЭС с ВВЭР. Представлена структура блока программ параметрической диагностики оборудования энергоблоков АЭС. Рассмотрена сущность методов и подходов параметрической диагностики оборудования энергоблоков.

\section{КОМПОНЕНТИ АВТОМАТИЗОВАНИХ ІНТЕЛЕКТУАЛЬНИХ СИСТЕМ ПІДТРИМКИ ПРИЙНЯТТЯ РІШЕНЬ НА ЕТАПІ ЕКСПЛУАТАЦЇ̈ І ДІАГНОСТИКИ УСТАТКУВАННЯ ЯДЕРНИХ ЕНЕРГОБЛОКІВ АЕС}

\author{
О.В. Сфімов, М.М. Пилипенко, Т.В. Потаніна, Т.О. Ссипенко, В.Л. Каверцев, Т.А. Гаркуиа
}

Представлено результати досліджень параметрів, характеристик та показників роботи енергоблоків АЕС методами математичного моделювання з використанням комп'ютерно-інтегрованих технологій їх реалізації, які дозволяють імітувати в процесі імітаційного експерименту множину функціональних станів систем та устаткування енергоблоків АЕС. Розроблено загальну структуру взаємодії блоків програмного комплексу для аналізу ефективності роботи і параметричної діагностики енергоблоків АЕС з ВВЕР. Представлено структуру блоку програм параметричної діагностики устаткування енергоблоків АЕС. Розглянуто сутність методів та підходів параметричної діагностики устаткування енергоблоків. 